Portland State University

PDXScholar

Engineering and Technology Management

Faculty Publications and Presentations

8-1-2015

\title{
Technology Assessment of Waste Disposal Technologies for Tillamook County
}

Jing Jiang

Biamp Systems Inc.

Abhishek Jain

Portland State University

Jonathan Lui

Portland State University

Jorge Garcia

Portland State University

Standley Limarta

Portland State University

Follow this and additional works at: https://pdxscholar.library.pdx.edu/etm_fac

Part of the Operations Research, Systems Engineering and Industrial Engineering Commons Let us know how access to this document benefits you.

\section{Citation Details}

Jiang, J., Jain, A., Lui, J., Garcia, J., \& Limarta, S. (2015, August). Technology assessment of waste disposal technologies for Tillamook county. In Management of Engineering and Technology (PICMET), 2015 Portland International Conference on (pp. 408-421). IEEE.

This Article is brought to you for free and open access. It has been accepted for inclusion in Engineering and Technology Management Faculty Publications and Presentations by an authorized administrator of PDXScholar. Please contact us if we can make this document more accessible: pdxscholar@pdx.edu. 


\title{
Technology Assessment of Waste Disposal Technologies for Tillamook County
}

\author{
Jing Jiang ${ }^{1}$, Abhishek Jain ${ }^{2}$, Jonathan Lui ${ }^{2}$, Jorge Garcia ${ }^{2}$, Standley Limarta ${ }^{2}$ \\ ${ }^{1}$ Biamp Systems Inc., Beaverton, OR - USA \\ ${ }^{2}$ Department of Engineering and Technology Management, Portland State University, Portland, OR - USA
}

\begin{abstract}
We propose a two-level filter system to evaluate the potential for alternative waste management practices by conversion of locally-generated waste products such as animal mortality, manure, and wood waste into beneficial products such as energy in Tillamook county of Oregon. At the first level - coarse grained filter, three basic factors, technical readiness level (TRL), scaling capacity, and feedstock, are used to initially filter out the scanned technologies which can be potentially used in waste management. At the secondary level filter - fine grained filter, a numeric scoring model is created to evaluate technologies from the output of the first level filter. Since many factors will impact the selection of a technology, HDM (Hierarchical decision model) is used to score technologies. From technical, economic, social, and environmental perspectives, hierarchical multi-criteria factor structure is created, and constant-sum and pair-wise comparison are used to subjectively create the priority probability list about technologies. Composting technology, rendering technology, and hydrolysis are analyzed in detail. This developed alternative strategy will help to mitigate local liabilities, promote green jobs, develop clean energy, and reduce the carbon footprint in Tillamook County.
\end{abstract}

\section{INTRODUCTION}

\section{A. Background}

Tillamook County and surrounding area have about 110 local dairies. These dairies are estimated to have a herd of 32,000 milking cows which generate approximately 233 million gallons of manure per year or 96,000 dry tons of manure and approximately 1700 tons of animal mortalities per year. Tillamook County is landfilling about twenty-four thousand tons of municipal solid waste each year, so about one thousand truckloads of municipal solid waste and two hundred thirty truckloads of animal mortalities are transported over one hundred sixty miles round trip to the Coffin Butte Landfill. The transportation may contribute to the carbon footprint of waste management practices. Locally handling waste resource would reduce or even eradicate the carbon footprint [1].

Tillamook County is researching and developing strategies for alternative disposal of animal mortalities because 110 local family-owned dairies depend on the County to haul their animal carcasses to the Coffin Butte Landfill in Corvallis, Oregon. The County is looking for alternative technologies to manage waste products in environment-friendly manner. The county intends to not only assist growth and development in the dairy industry but also minimize environmental, economic, and public health impacts. There is a need to find out if it is technically and economically feasible to use alternative waste management practices to help the county to manage waste products.
Alternative disposal options include the evaluation of anaerobic digestion, composting and/or other emerging technologies to transform these waste products into a viable resource that can produce a renewable energy source or maintain sustainable development of the county.

\section{B. Technology Assessment}

The origins of the field of Technology assessment can be traced to technology forecasting studies in the 1950s. These studies attempted to forecast technological trends. Technology assessment (TA), first developed in the United States in the late 1960s, plays an important role in technology management. On October 13, 1972, the Technology Assessment Act was put into law and the Office of Technology Assessment (OTA) was created based upon the Act. OTA has responsibility to provide Congress with authoritative and unbiased reports on a wide range of present and emerging issues in science and technology because Congress needed an earlier awareness, an earlier warning, and an earlier understanding of what might be the social, economic, political, ethical and other consequences of the introduction of a new technology into the society or a substantial expansion of an existing technology [2]. Joseph F. Coates [3] defined TA as "the name for a class of policy studies which attempt to look at the widest possible scope of impacts in society of the introduction of a new technology. Its goal is to inform the policy process by putting before the decision maker an analyzed set of options, alternatives and consequences". TA has no doubt to be a concept to assist in public policy decision toward emerging technologies.

No single methodology can be sufficient for all requirements of $\mathrm{TA}$. In order to assess all areas of a technology, TA has to be performed via multi perspectives and multi-criteria approaches. Technologies can be analyzed from political, economic, social, technological perspectives (PEST), from social, technological, economic, environmental, and political perspectives (STEEP) perspectives, from political, economic, social, technological, environmental, and legal perspectives (PESTEL), or from political, economic, social, technological, legal, environmental, and demographic perspectives (PESTLED) [4, 5]. The dimension of perspectives should be selected based upon the application of technologies. In each perspective, multi-criteria will be created to evaluate technologies. Different technologies and different application will need different criteria.

Tillamook involves many stakeholders and the waste process and management must be considering from multiple perspectives and multi-criteria. Technological, Economic, Environmental, and Social perspectives need to be applied to evaluate the technologies potentially used in processing and 
managing waste in Tillamook. The paper covers technology assessment criteria and evaluating scoring model, technology assessment process, and result analysis.

In technology assessment criteria and evaluating scoring model section, technology assessment methodology, technology screening methodology, and technology fine grained assessment are discussed; technology assessment criteria are defined. These criteria are classified as technical factors, environmental factors, social factors, and economic factors; Based upon these criteria, Hierarchical Decision Model (HDM) are created to weight potential technologies.

In technology assessment process section, technology scanning is demonstrated, and then technology analysis is carried out. Technology scoring, pair-wise and constant sum comparison, is discussed in detail.

In the result analysis section, the constant sum and pairwise comparison results are analyzed. Technologies scores against different perspective and factors are given.

\section{TECHNOLOGY ASSESSMENT CRITERIA AND EVALUATION SCORING MODEL}

\section{A. Technology Assessment Methodology}

A two-level filter is proposed to evaluate potential technologies which can be used in Tillamook for waste processing and management. The Figure 1 below shows the flowchart of the process for the technology assessment.

\section{B. Technology Screening Methodology}

The input of the flow is the scanned technologies which have potentials for waste process and management. Technology screening provides the foundation for subsequent work. In order to identify optimal waste processing technologies, the following approaches will be used to scan technologies:

- Literature - perform to an extensive literature review to identify new technologies and to evaluate their performance and applications. Literature includes published literature and informal literature such as Vendor-supplied information, Internet research, and consultants' technical reports.

- Technical Associations - contact a variety of professional and technical associations to identify emerging wastewater treatment technologies.

- Interviews and Correspondence - consult consultants, academics, and municipal wastewater treatment plant owners and operators.

\section{Technology Coarse Grained Assessment}

The first level is called as the coarse grained filter. Three basic factors: technical readiness level (TRL), scaling capability, and feedstock, are used to exercise this filter and produce its outputs.

TRL has been widely discussed about the definition and application $[6,7,8,9,10,11,12]$. However, the senility and death isn't given too much attention. The Figure 2 shows the readiness levels and technology life cycle. A technology needs to meet at least TRL7 and isn't in the senility \&death phase. In TRL7, the technology has been finished for system prototype in an operational environment. It has been proved that the technology operates well in the actual environment. This will lower the risk in implementation of this technology. The scaling capability is to see if the technology can be implemented in a commercial level. The feedstock is to see if the technology can use the materials (animal carcasses, manure, and wood waste) generated in Tillamook. Some technologies may need either a mix of three or one of three.

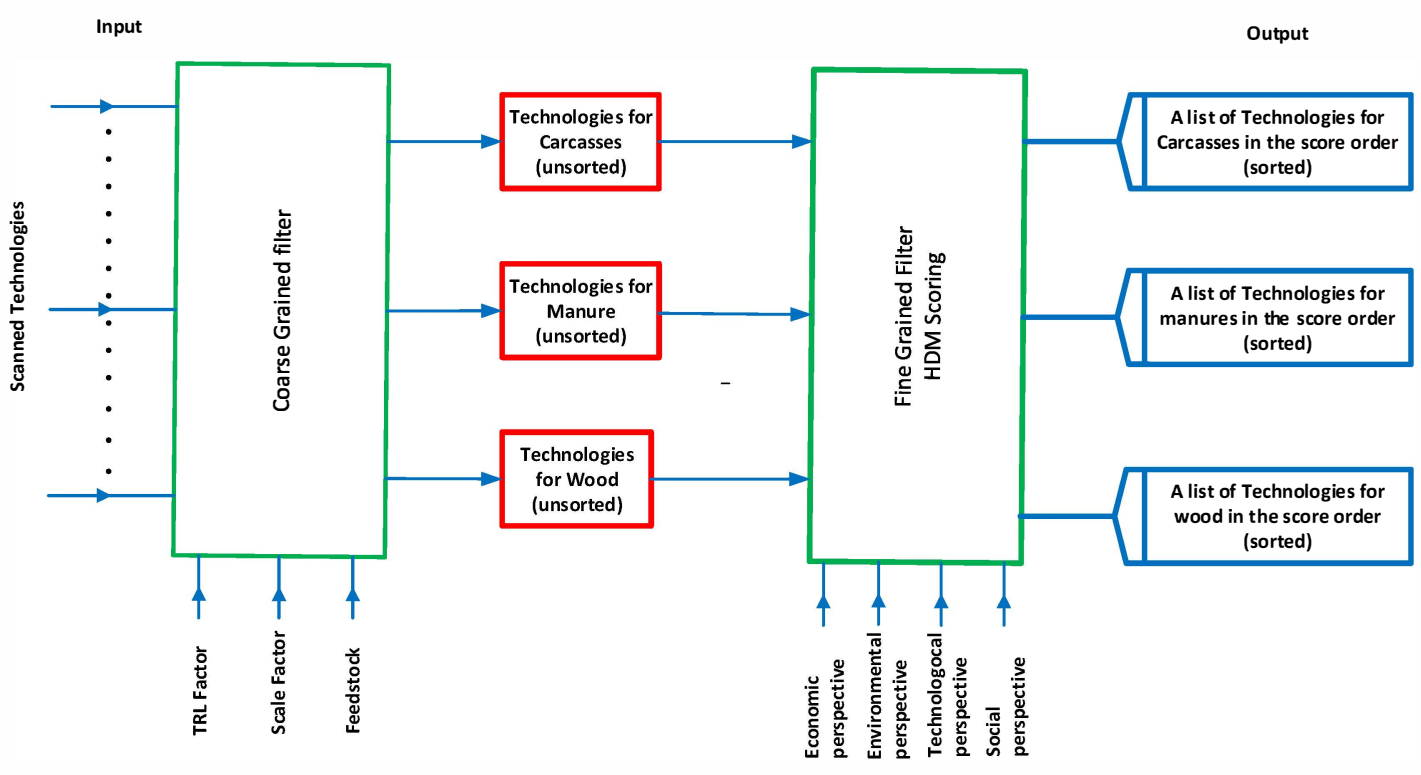

Figure 1 - A Two-level Filter Model for Technology Assessment 
2015 Proceedings of PICMET '15: Management of the Technology Age

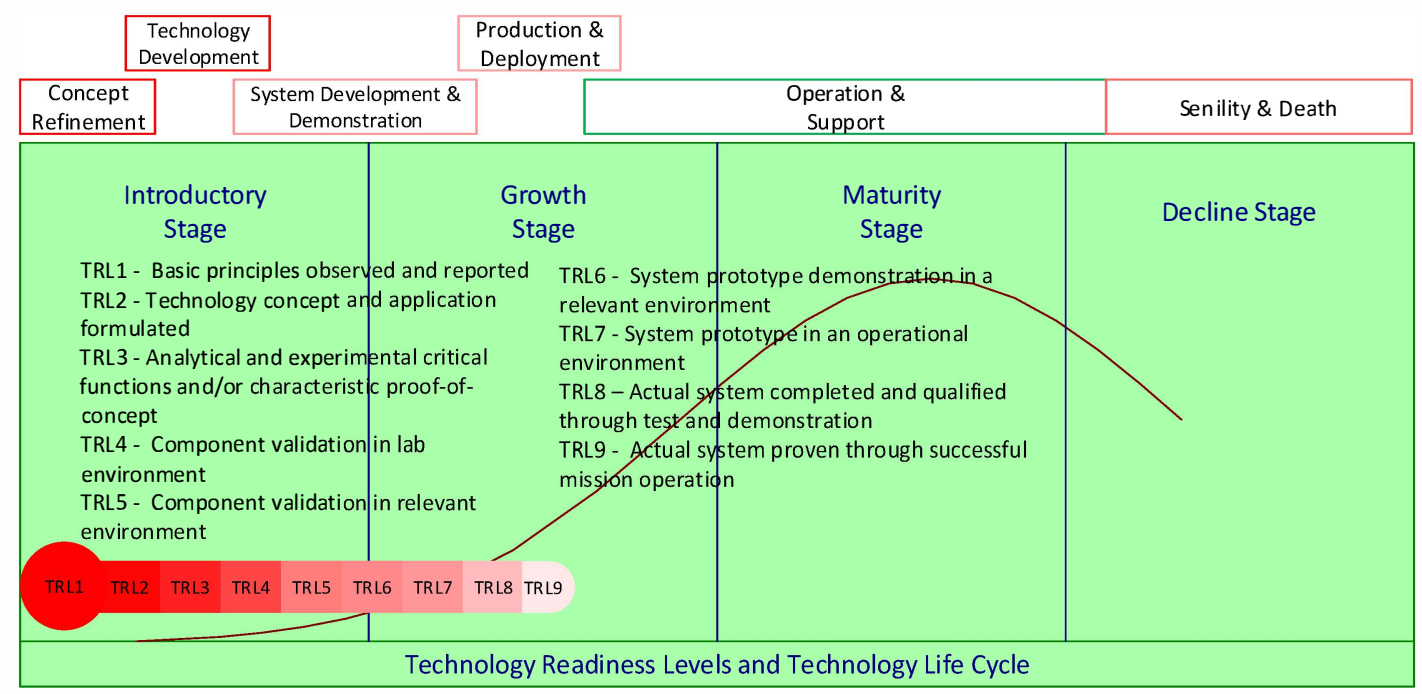

Figure 2 - TRL and Technology Life Cycle

\section{Technology Fine Grained Assessment}

The output of the first level filter is used as input into the second level filter called "The Fine Grained Filter". In this filter, technologies will be scored by a HDM using multiple perspectives: Technological perspective, Economic perspective, Social perspective, and Environmental perspective. The output of this filter is a list of technologies with a numeric values. The technology with the largest numerical value should be the optimal technology, so the decision maker should seriously consider it. In the following sections, we will define the multi-criteria for each perspective and discuss the HDM methodology.

\section{E. Technology Assessment Criteria}

Technical Factors - All the technologies are being assessed based on their adaptability, reliability, process duration, efficiency, area requirements, and engineering requirements [5].

- Adaptability: Ability of using the technology regardless of the factors or concern where it needs to be used.

- Efficiency: The ratio of output to input is how the efficiency is defined; technology efficiency talks about the same ratio for the disposal technologies, input (the material to be disposed) and output (the amount of material that is disposed).

- Area Requirements: Disposal technologies have different features and characteristics. They even need different amount of area to setup a facility or use it.

- Engineering Requirements: Amount of engineering is needed to keep the facility running or maintain its efficiency. They depend on the complexity of the technology equipment that is being used.

- Reliability: It's the ability of the technology process to perform correctly and efficiently at all times.

- Process Duration: It is the duration the disposal technology takes to complete dispose of the waste into some useful byproducts that are much less or not at all harmful compared to the initial waste that was fed to them to dispose.

Environmental Factors: Waste disposal technologies have been into existence since centuries, but over the past few decades the decomposing capacity is been out run by the tons of waste being produced. Enormous amounts of waste themselves have led people to environmental awareness, further with tremendous environmental degradation over the years. Environmental impacts can never be ignored, so it leads technology experts and stakeholders questioning about the air, soil and water contamination by these disposal technologies. There have been rising concerns over the effluents produced during the disposal and the residual products in regard to environment [5].

- Air Pollution: The impact of the final output products after disposing process has on air that will pollute it.

- Soil Contamination: The impact of the final products after disposal that are added to soil for further decomposition, can be of some or a lot harm that can contaminate the soil.

- Water Contamination: The impact of the final products on the water if added to any of the water streams can be contaminating.

- Hazardous Byproducts: Along with less harmful, some harmful or hazardous products may also be the result of the disposal technology and they need to be decomposed safely.

Social Factors: They are impacts of the technology and the effluents and the products produced using these technologies on the nearby human community. Waste disposal technologies have been into practice since very long, making a mark in the current industrialization and becoming an important part of the human life. Without these industries earth will be turning up into a garbage bin much faster than 
anyone can expect. Although these technologies play an important role in curbing the growth of waste, there are certain impacts that can be harmful or can be dangerous to the society to certain extent. It is important to identify these factors and improve them further to reduce their impacts. Currently some of the articles describe about bio-aerosols being released in the environment from the composting sites being spread up to 200 - 500 meters that can be harmful for the people residing in that radius of the composting site [5].

- Public Health: Disposal technologies result in different residues and effluents that may affect public health and is of concern. Hence all the technologies need to follow the EPA regulations to keep all harmful constituents under the limit.

- Public Safety: Impact on the welfare and protection of the general public.

- Employment Creation: With the new facilities opening in different areas to curb the increasing waste, it also creates employment for the people in that area.

- Odor: Different odors are released from the type of waste the technology is decomposing from animal carcasses to timber waste. Some methods release some stringent smell that is too stringent for the people in the surrounding to bear; hence it is a factor that need not be neglected. These odors can be reduced by addition of certain substances in the process.

Economic Factors: The economic factor considers several aspects of the disposal technologies like the setup cost of the plant, labor cost, operating and maintenance cost, transportation and any other additional expenditure that might go into it. Each technology has a different sets of costs attached to them, and not all technologies are able to regain the initial investment. Therefore the cost becomes an important factor of all technologies being assessed, in a process to identify the best economic way to decompose the present waste [5].

- Set-Up Cost: The initial investment or capital is needed to open any new venture. It varies from few thousand dollars to millions of dollars depending upon the plant size.

- Labor Cost: Any plant or facility needs labors for its mechanical, physical and other tasks, which result in their monthly salaries. These salaries are recorded in the expenses in cashbook and vary from number of labors to type of labors the facility hires.

- Operation \& Maintenance Cost: Day to day operations of facilities incorporate some cost to keep the facility running further the equipment needs maintenance during their useful life.

- Revenue: The disposal technologies results in different products like biofuels, sugars that earn the facility revenue in return.

- Transportation Cost: The cost to transport the material to the process facilities.

\section{F. Evaluation Scoring Model}

Hierarchal Decision Model (HDM) along with Important Weighting System is used to analyze the importance of each criterion in respect to different waste disposal technologies chosen for assessment in this research. The first three levels of the HDM will be rated by the five team members of the research group using pair wise comparison and the last level considering the technologies will be rated by the same members using a weighting system. The flow chart describes the various levels of technology assessment and the methodology used to rate each level. The technology with the highest end score will be best suited for Tillamook County.

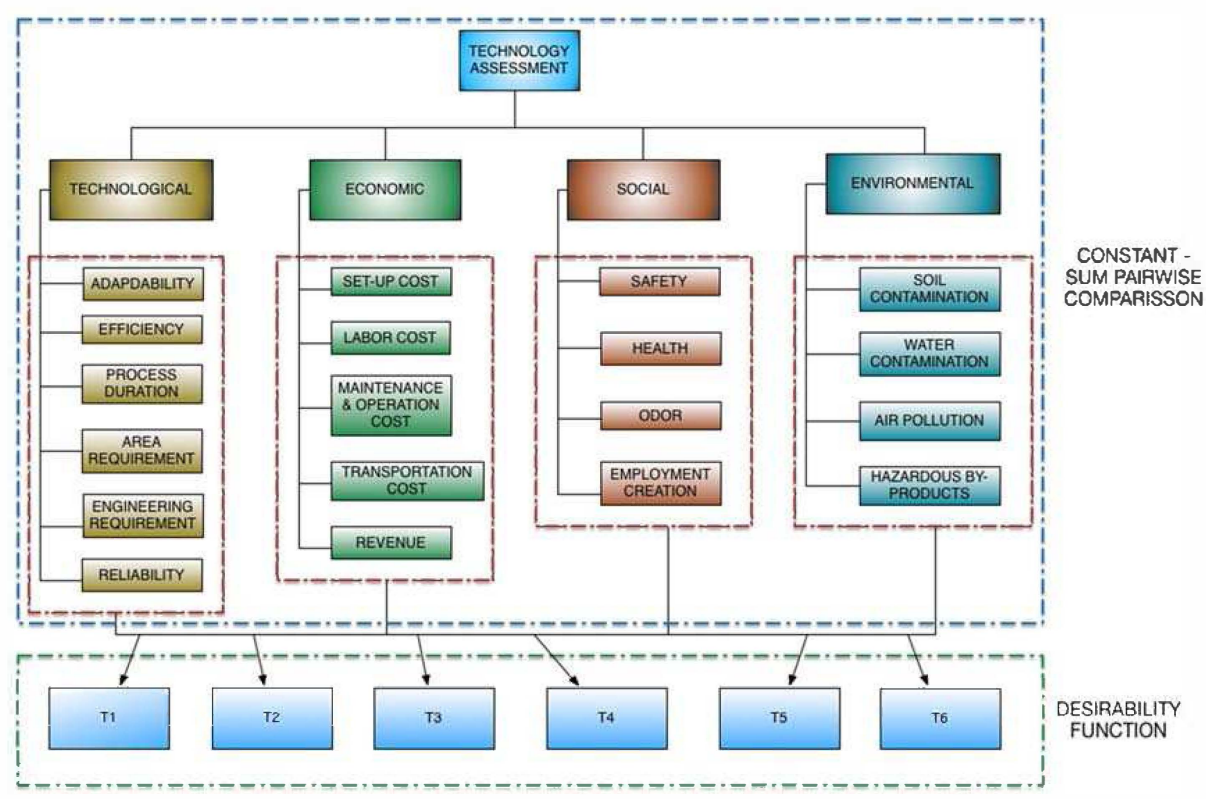

Figure 3 - Hierarchal Decision Model 
2015 Proceedings of PICMET '15: Management of the Technology Age

\begin{tabular}{|c|c|c|c|}
\hline Technologies & TRL verification & Scaling verification & Feedstock verification \\
\hline Burial & pass & pass & pass \\
\hline Rendering & pass & pass & pass \\
\hline Anaerobic digestion & pass & pass & pass \\
\hline Thermal gasification/pyrolysis & pass & pass & pass \\
\hline Plasma arc & pass & pass & pass \\
\hline Composting & pass & pass & pass \\
\hline Vermicomposting & pass & none & none \\
\hline Incineration & pass & pass & pass \\
\hline Alkaline hydrolysis & pass & pass & pass \\
\hline Lactic acid hydrolysis & pass & pass & pass \\
\hline Enzymatic hydrolysis & pass & pass & pass \\
\hline Gasification & pass & pass & pass \\
\hline Re-feeding & pass & none & none \\
\hline Ocean Disposal & pass & none & none \\
\hline Non-traditional rendering & pass & pass & none \\
\hline Novel pyrolysis technology & none & none & none \\
\hline Thermal de-polymerization & pass & pass & none \\
\hline Extrusion & pass & pass & none \\
\hline
\end{tabular}

\section{TECHNOLOGY ASSESSMENT PROCESS}

This section will apply the proposed methodology in the process of technology assessment. The process includes three steps: technology scanning, technology analysis, and technology scoring.

\section{A. Technology Scanning}

We use the approached for technology scanning to find out the following technologies which can be used for waste management $[13,14,15,1,16,17,18,19,4,20]$ [21].

\section{B. Technology Analysis}

The scanned technologies are injected into the TA system. A list of technologies is left for further evaluation:

TABLE 2 - TECHNOLOGIES FOR FURTHER EVALUATION
\begin{tabular}{|l|}
\hline Technologies for further evaluation \\
\hline Burial \\
\hline Rendering \\
\hline Anaerobic digestion \\
\hline Thermal gasification/pyrolysis \\
\hline Plasma arc \\
\hline Composting \\
\hline Incineration \\
\hline Alkaline hydrolysis \\
\hline Lactic acid hydrolysis \\
\hline Enzymatic hydrolysis \\
\hline Gasification \\
\hline
\end{tabular}

TABLE 3 - TECHNOLOGIES TO BE EVALUATED

\begin{tabular}{|l|}
\hline \multicolumn{1}{|c|}{ Actual technologies to be evaluated } \\
\hline Rendering \\
\hline Windrow Composting \\
\hline Static Pile Composting \\
\hline In-Vessel Composting \\
\hline Alkaline hydrolysis \\
\hline Enzymatic hydrolysis \\
\hline
\end{tabular}

Because of the time limitation, it is not possible for us to evaluate all technologies mentioned in the table above.
Composting, Rendering, Alkaline hydrolysis, and Enzymatic hydrolysis are determined to perform further analysis.

\section{Rendering}

Rendering technology is no stranger to North America. It has been a major force in maintaining a clean environment over the past century [22]. Every year rendering facilities throughout North America recycles approximately 59 billion pounds of animal mortalities into a more useful material that is used in ingredients for various soaps, paints and varnishes, cosmetics, explosives, toothpaste, pharmaceuticals, leather, textiles, and lubricants [22]. For half a century, Oregon had two in-state rendering plants that handled and processed more than 40 thousand tons of animal mortality and meat processing byproducts from butchering beef, pork, sheep, and poultry [23]. However, the two Oregon rendering plants both closed in 2006, due to certain circumstance [23].

The Oregon companies each followed a traditional rendering business model. Fig. 4 is a typically rendering process layout [24]. They collected animal wastes with their own trucks from meat processing and retail meat and bring it back to their own processing facilities. The process starts with the collection of "offal" refers to butchered animals parts that are considered "inedible" (meaning not consumed by humans). The animal byproducts include: hides, skins, hair, feathers, hoofs, horns, feet, heads, bones, toe nails, blood, bones, organs, glands, intestines, muscle and fat tissues, shells, and whole carcasses. The finished products derived from the processing of animal byproduct are poultry grease, meat and bone meal, poultry meal, and blood meal [24]. The fats and proteins from these products are then made into products that are to be used for non-edible purposes or consumed by animals, poultry, and fish.

Over the years the demand for rendering byproducts has gone down. Due to the discovery of bovine spongiform encephalopathy (BSE), commonly known as mad cow disease, it has raised concerns about possible disease transmission to humans and animals through the processed of 
animal byproducts, resulted in the less demand for the animal byproducts [23]. The amount of exports of inedible fats surely declined (see Figure 5).

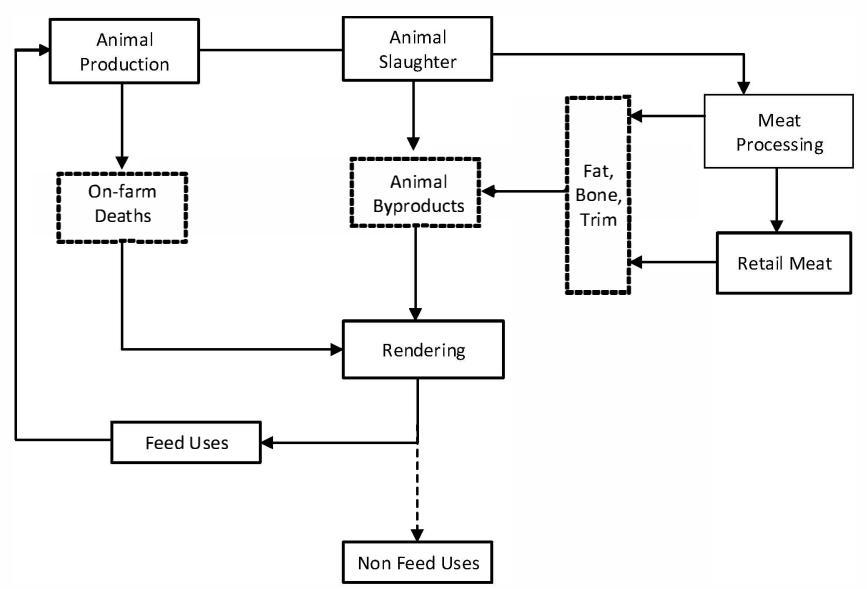

Figure 4 - A Typically Rendering Process Layout

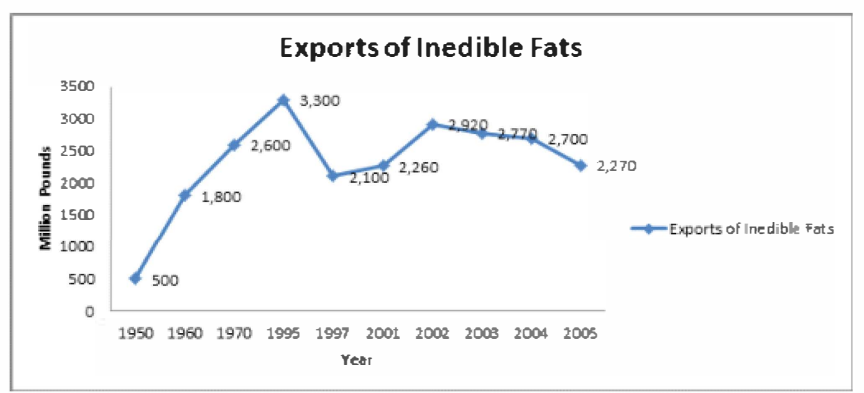

Figure 5 - Exports of Inedible Fats

In addition, import goods have increased supplies of products that are generally made from rendering facility, resulting in much lower prices. Combined with the environmental issues, these two circumstances played a large rol'e in the closure in 2006 of the two Oregon rendering companies.

Based on our literature review and interview, the outlook for rendering returning to Oregon is unlikely for the time being. The current response in the rendering industry is that the well-known independent renderers have already established a foothold in Oregon such as Darling International and Baker Commodities. As demonstrated in Oregon, the small independent renderers will have to face some serious competition and will find it more difficult to compete under certain conditions where it may lead to the ceasing of operations. If Oregon wants to revive the rendering business, it will either have to find a way to get public incentives or receive state and local government funding to help cover cost. According to the Cascade Economics report, they projected that the required capital cost to construct a modern rendering plant (with the proper environmental equipment that meets environmental standards) would be a total of $\$ 7.5$ million or more [23].

\section{Composting}

Composting is a natural process where water and air are the primary agents used to decompose or break down organic material. The resultant material is used as food to feed microorganisms which break it down into simpler compounds. The simpler compounds are then digested by soil microbes to produce nutrients which can be used by plants [25]. The Figure 6 shows the basic composting process.

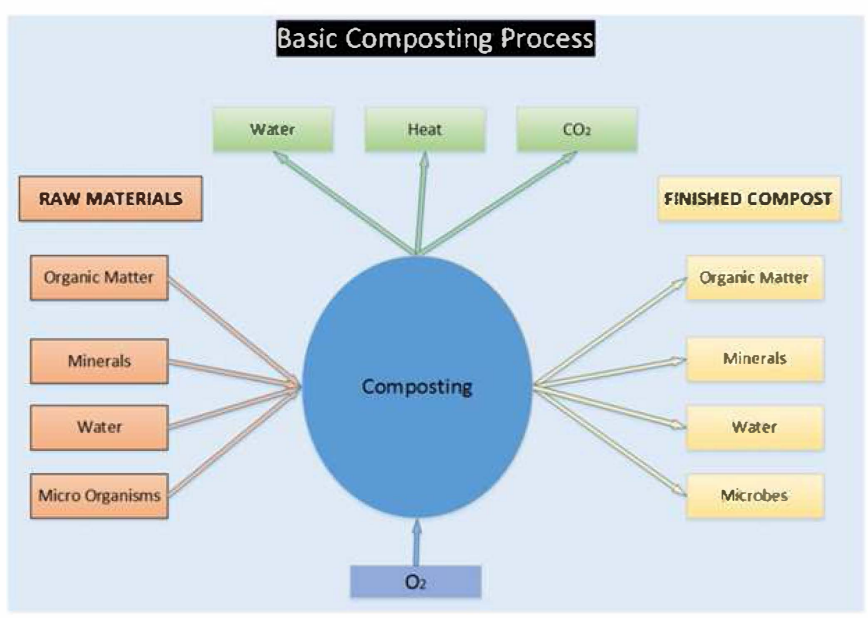

Figure 6 - Basic Composting Process

The composting process has been used for many generations around the world. Waste pits made of stone and built outside houses have been found in Sumerian cities about 6000 years ago. In these pits, organic urban wastage was stored for eventual application on agricultural fields [13]. Composting, therefore, is a technology tried for millennia, and proven to be effective and safe. Composting has been adapted in multiple ways, and as time has passed more and more advances have made composting more efficient and safer. At the same time, human kind has developed methods for composting more and more waste materials. Composting has become a common way for recycling waste products, and avoids the need for larger and larger landfills.

Odor is becoming one of the main drawbacks of composting, so that it is one of the primary concerns to the public [26]. The livability of a city is dependent on its cleanliness; citizens like to leave in clean, fresh, and healthy locations. Therefore, a malodorous city with poor sanitation is a place that does not attract inhabitants and is a place with poor living standards.

Wind-Row, Static-Pile, and In-Vessel are three commonly used methods of composting.

\section{a) Windrow Composting}

This is the most commonly used form of composting. The compost is piled into rows and the feedstock is periodically turned to control the mixing, the temperature, and the moisture of its contents. The advantages are its ease of construction and maintenance, as well as its low price. The 
main limiters are land area and potential smell effects. The disadvantages of Windrow composting are the constant turning that must take place in order to properly control the temperature and moisture of the material. Another issue is the length of time that it takes for a final composting product to emerge, from 4 to 8 months depending on turn frequency. Finally, the biggest drawbacks are the concerns of weed seeds surviving into the final product and the probability of living pathogens not being killed during the process [27].

\section{b) Static-Pile Composting}

This is the simplest and least expensive form of composting, the main differences compared to windrow, is its ease of construction and maintenance. The material is piled and left sitting with no need for mixing of the feedstock material. The biggest drawbacks, in addition to the ones mentioned for windrow, is the low quality of the composting and the length of time it takes to complete from 6 to 24 months [27].

\section{c) In-Vessel Composting}

This form of composting requires the biggest amount of design resources. It is usually used for high volume composting and requires the highest level of management compared to other forms of composting. High start-ups costs are common because buildings are usually needed to house the facilities. The biggest advantage of In-vessel composting is its ability to control the environmental elements because of its enclosure and its ability to control odors. It takes the shortest amount of time to process wastes [27].

\section{Hydrolysis}

Hydrolysis is a chemical reaction when the pure water flowing through is attacked by electrophilic hydrogen atom of the $\mathrm{H}_{2} \mathrm{O}$ molecule on the glycosidic oxygen [28]. It is to process the substances with higher temperature, higher pressures and the pick the right catalyst [29]. It is a relatively slow process because of recalcitrance of cellulose.

This technology has been used for many years especially when the chemical process become a commercial use. Hydrolysis has been developed to become effective and safe technology and adapted in multiple ways. It has become easier and less complicated process.

Increasing Wastes and Energy consumption have been inspired using this technology to convert the biomass feedstock into Biogas. One of the products of biomass producing with hydrolysis is Bioethanol produced by converting biomass biopolymers into fermentable sugar [30]. Bioethanol can be produced from Sucrose rich feedstock, starchy material, and lignocellulosic.

There are many Hydrolyses technology that have been developed in the last past decades. Some of the technologies are mature and some of them are still in the development stage. We will concentrate on two commonly and commercially used method of the hydrolysis: Enzymatic and alkaline.
Hydrolysis has many advantages and disadvantages. The paper will highlight major ones and try to elucidate the most important factors by using two different hydrolysis technologies available.

The most significant issue which communities face with this technology is the cost of the technology because this technology has more complex process and requires significant engineering skill to operate and maintain the technology. The other drawback of this technology is that the government regulation may impact the price and demand of bioethanol [31].

Pretreatment would be a critical step. It will affect the quality and the cost of the carbohydrates containing streams. Pretreatment is used to remove the lignin layer, hemicellulose, reduce the crystallization of cellulose and increase the porosity of the lignocellulosic materials so it will easier and faster access the biopolymers. Lignocellulosic are mainly composed of cellulose, hemicellulose, and lignin [32]. Cellulose is a homopolysaccharide composed of $\beta$-Dpyranose units. Hemicellulose is a mixture of polysaccharides, including pentoses and hexoses. Lignin is the most complex natural polymer consisting of a predominant. Pretreatment method could be classified into several categories such as physical, physiochemical, chemical, biological, electrical or combination [30]. They have to meet the following requirements[32]:

1. Improve the formation of the sugar or ability to subsequently form sugars by hydrolysis

2. Avoid the degradation or loss of carbohydrate

3. Avoid the formation of byproduct that are inhibitory to the subsequent hydrolysis and fermentation process

4. Be cost effective.

\section{Enzymatic Hydrolysis}

Differentiation enzymatic with other hydrolysis is the material used to break the cellulose. In the enzymatic hydrolysis, the used enzymes are microorganisms such as bacteria and fungi secrete soluble extracellular enzymes known as non-complexed cellulose system, anaerobic cellulolytic microorganism producing complexed cellulose system, and Cellulose-degrading strategy. Non-Complexed cellulose system is the most popular and fully examined. It uses saprobic fungus producing efficient extracellular enzymes [28]. The process is slow but can be improved by $\beta$ glucosidases. The enzymatic hydrolysis performs under mild condition, e.g. $\mathrm{pH} 4.5-5.0$ and temperature $40-50^{\circ} \mathrm{C}$ [31].

After the pretreatment, the next step is the bioconversion of lignocelluloses. There are two biopolymers hydrolysis and the sugar fermentation which can be performed: simultaneous saccharification and fermentation (SSF) [29], separate hydrolysis and fermentation (SHF) [29], simultaneous saccharification and co-fermentation (SSCF). SHF could have different temperature so it can maximize enzyme but the process would take longer than SSF. 
The advantages of enzymatic hydrolysis are:

- Enzymes are highly specific uses. Each waste has its own characteristics so enzymes should be optimized to shorten the process and increase the productivity especially largescale and specific industry [31].

- The process can work at mild process conditions temperature $40-50^{\circ} \mathrm{C}$ [31], so it will reduce the energy for the process and extend the container life span, and decrease the maintenance cost [31].

- Catalysts can be easily recovered and reused for many reaction loops [28] so that increase the efficiency and lower enzyme mix consummation.

- Biofuel can be produce as new renewal energy so we can reduce the usage of fossil fuel and generate more eco friendly products [33]. Because the enzyme cost (Figure 7) drops from $\$ 4.5 /$ gallon to $\$ 1.50 /$ gallon, production cost (Figure 8) drops from $\$ 8.0 /$ gallon to $\$ 3.0 /$ gallon [34].
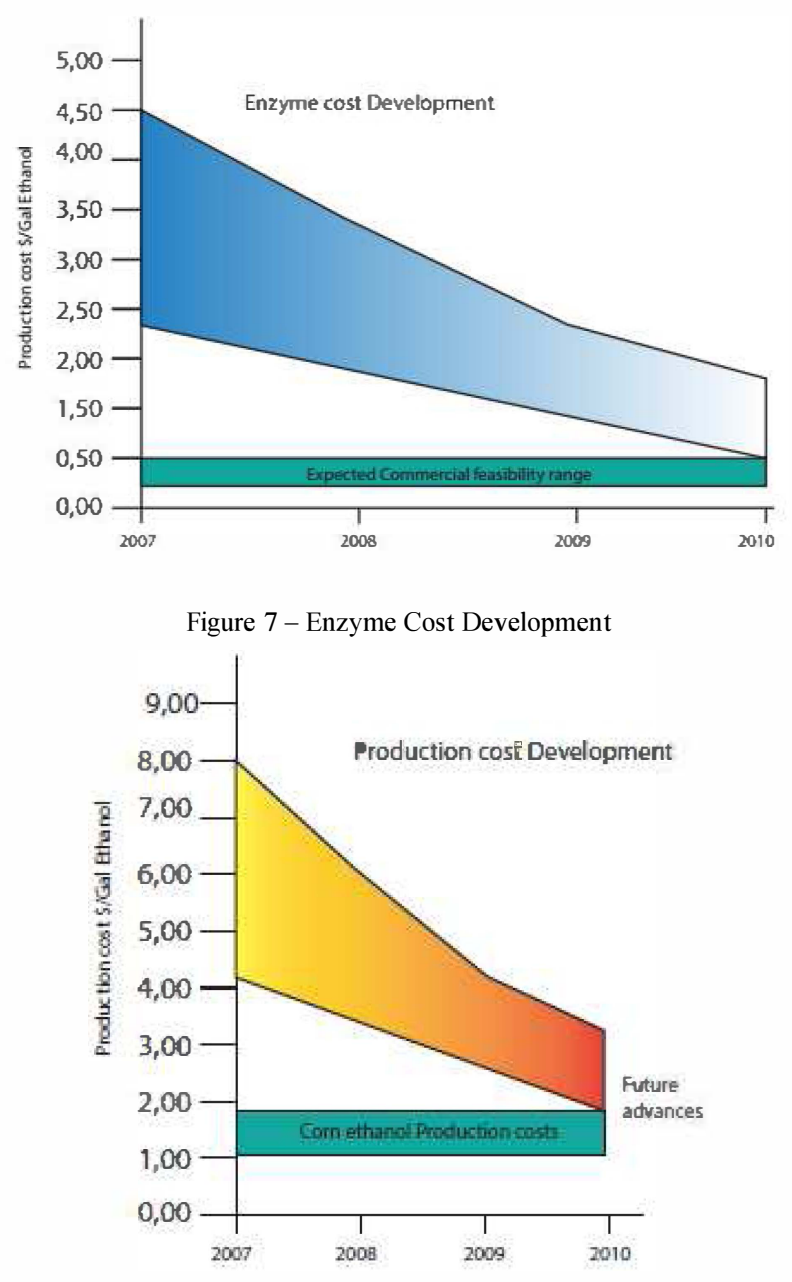

Figure 8 - Production Cost Development

The disadvantages of enzymatic hydrolysis are:

- The costs of enzymes isolation are relatively high [28]. The enzymes are relatively unstable at high temperature [31].
- Price of the ethanol is relatively unstable but it would be related to the government regulation [35].

- The hydrolysis is relative complicate and require advance chemical engineering knowledge and skill to operate and maintain the process [33].

\section{Alkaline Hydrolysis}

Alkaline hydrolysis is been known for a while, Amos Herbert in 1888 was granted U.S patent and has been even documented and registered in Federal books since 1970s as approved technology to treat and reduce animal waste [36] [37]. Earlier the humans burn or bury the carcasses of animals, and then they learnt to dissolve carcasses into sluggish liquid through alkaline hydrolysis technology [37]. Over the years the technology has been evolved and enhanced, recently used in bio-containment with alkaline chemicals. Dr. Gordon Kaye and Dr. Peter Weber modernized the technology in 1992 at the University of Albany; successful outcomes of early testing led to developing a company to supply alkaline hydrolysis technology that several lower classification containment labs started using for the treatment of waste streams [37]. Although the technology has been known over the years, major breakthrough development was around 16 to 20 years ago due to the efforts of Dr. Kaye and Dr. Weber.

The alkaline hydrolysis process has been adapted for biological tissue disposal in medical research institutions as well as carcass disposal. The process uses 5 to 10 percent of sodium hydroxide or potassium hydroxide of the weight of caustic potash or its equivalent of the matter being dissolved; acting as a catalyst in the alkaline chemical reaction to break down proteins, nucleic acids, carbohydrates, lipids, etc. into a sterile aqueous solution consisting of small peptides, amino acids, sugars, and soaps. Heat and pressure at 150 degree Celsius further accelerates the chemical reaction taking 3 hours to dispose animal carcasses [36] [38]. The final byproducts consist of solid residue due to mineral constituents of bones and vertebrates that are the undigested and account for only two percent of the original weight and volume of carcass materials.

The current modernized process is carried out in a tissue digester that consists of an insulated, steam-jacketed, stainless steel pressure vessel with a lid that is manually or automatically clamped, similar to a pressure cooker [38]. The vessel contains a retainer basket for bone remnants and other materials. The process releases no emissions into the atmosphere and results in only minor odor production. The end product is sterile, coffee colored, alkaline solution with a soap-like odor that can be released into a sanitary sewer in accordance with local and federal guidelines regarding $\mathrm{pH}$ and temperature.

Advantages and Disadvantages of the Alkaline Hydrolysis:

The technology has many advantages over the other existing disposal technologies out in the market. In hydrolysis process, the carcass is converted to sluggish solution and 
some remaining bones that are not so harmful and are $97 \%$ less in weight and size compared to initial weight and size of the body. The solution is safe to be released in sewer after reducing the $\mathrm{pH}$ value, not producing much air particles that can create air pollution. It produces much less greenhouse gases compared to other carcass disposing technologies [38]. Although the technology also gets rid of infected, radioactive tissues and has a sterilized reaction, it uses a large amount of energy during the process.

\section{Technology Scoring}

\section{Pair-Wise and Constant Sum Comparison}

The team members are those experts to perform the survey because of the time limitation. Based upon our literature review, all members in the team have enough knowledge to do the pair-wise comparison to get subjective priority probabilities of these defined criteria. Fortunately, we don't need to manually perform these calculations. A web based HDM developed by Portland State University is used to calculate these subjective probabilities (Figure 10).

\section{Desirability Function Creation}

In order to score each technology, desirability function needs to be created. The intention is that the quality of a product or process consists of multiple performance measures or quality characteristics and these characteristics need to be in a desired range. This approach can identify the characteristic value(s) that provides the highest desirability. A desirability value can be in a range of 0 to 100 .

The desirability functions represent the mapping of technological characteristics or performance measures to a desirability value in the range of 0 to 100 . A value of 100 is most desirable, and 0 is unacceptable. The desirability function is plotted as a curve for a range of performance measures. The curve may be linear, nonlinear, and even multimodal. The following methods can be used to develop the desirability function [39]:

- Direct plotting on grid

- Pairwise comparisons

- Standard gamble

The simplest method is direct plotting. In the paper, direct plotting is used to create desirability functions. Web based software, Qualtrics, is used to develop our desirability functions (Figure 9). A panel of experts (team members) objectively scores technologies under investigation against all defined criteria. A mean value will be used for desirability functions.

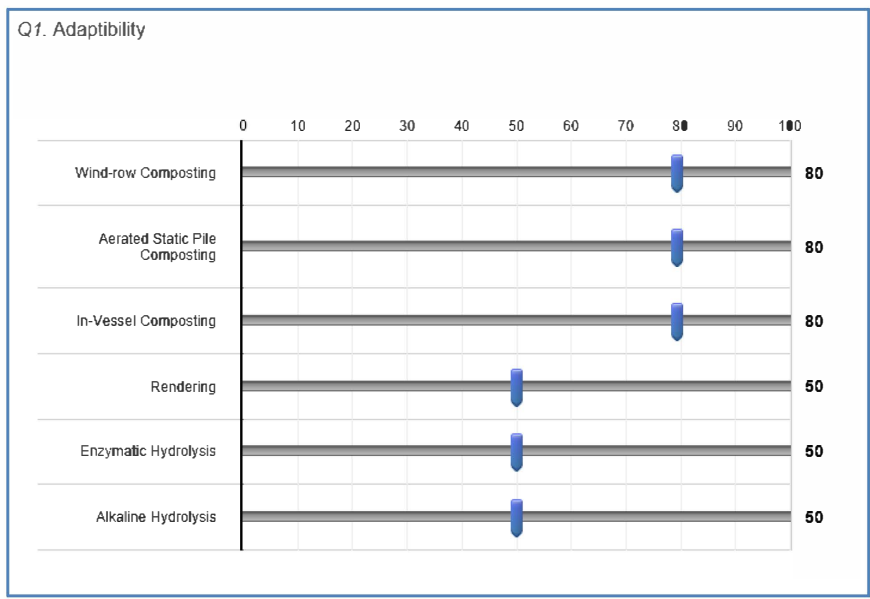

Figure 9 - Desirability Function Development

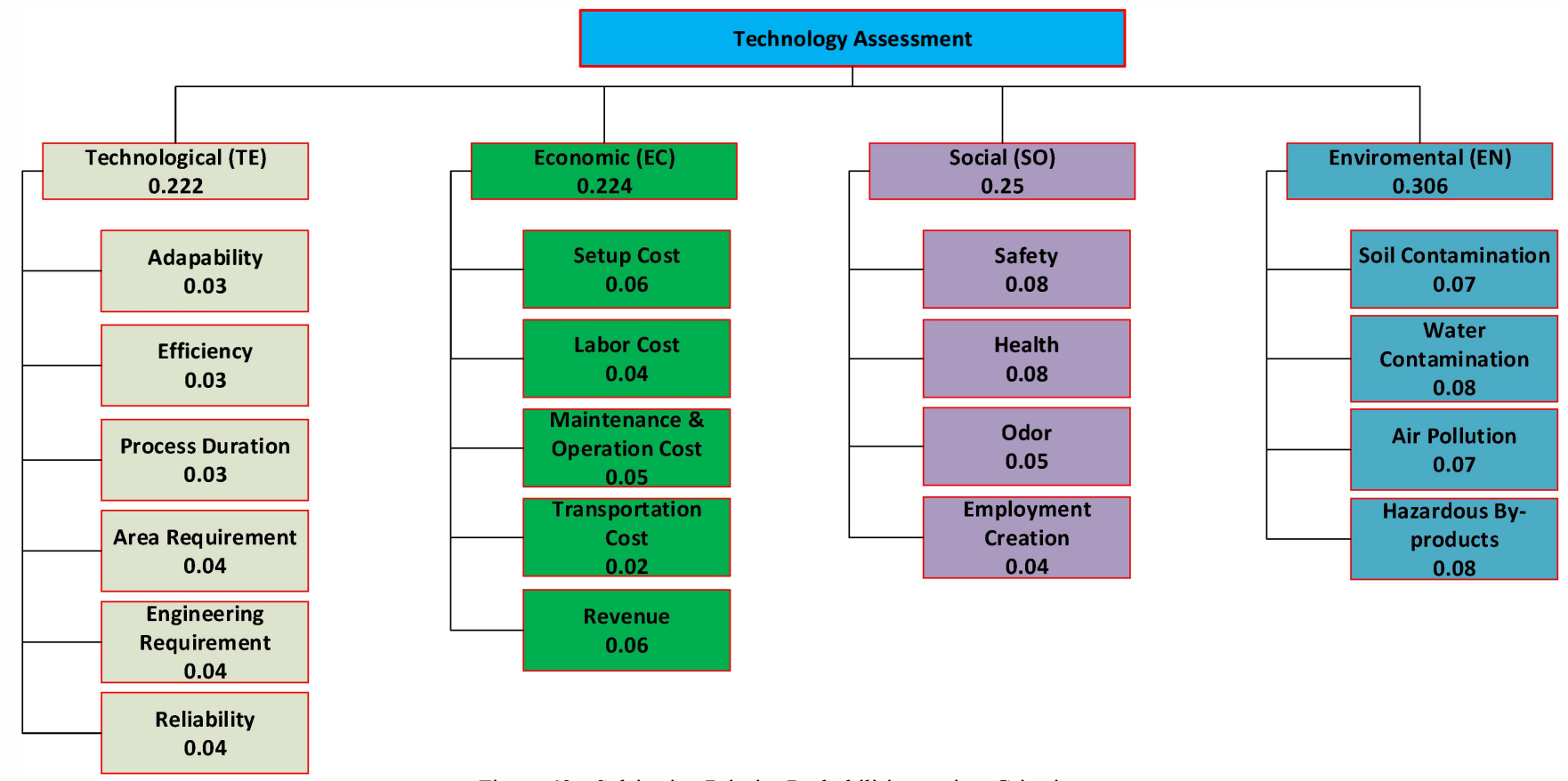

Figure 10 - Subjective Priority Probabilities against Criteria 
After we have subjective priority probability and desirability function against each of criteria, we can have a subjective score for each technology under evaluation.

\section{RESULT ANALYSIS}

Table 4 and Table 5 show the constant sum and pairwise comparison results. The inconsistencies of both results are 0.01 . It means experts all have same opinion about those perspectives and criteria.

\begin{tabular}{|c|c|c|c|c|c|}
\hline & Technological & Economic & Social & Environmental & Inconsistency \\
\hline Expert 1 & 0.22 & 0.27 & 0.19 & 0.32 & 0 \\
\hline Expert 2 & 0.21 & 0.21 & 0.29 & 0.29 & 0 \\
\hline Expert 3 & 0.24 & 0.15 & 0.33 & 0.28 & 0.02 \\
\hline Expert 4 & 0.22 & 0.33 & 0.19 & 0.26 & 0.01 \\
\hline Expert 5 & 0.22 & 0.16 & 0.25 & 0.38 & 0.01 \\
\hline Mean & 0.222 & 0.224 & 0.25 & 0.306 & \\
\hline Minimum & 0.21 & 0.15 & 0.19 & 0.26 & \\
\hline Maximum & 0.24 & 0.33 & 0.33 & 0.38 & \\
\hline
\end{tabular}

Figure 11 and Figure 12 shows examples of desirability functions with nonlinear regression. The best value is 100 , and the worst value will be zero.

Figure 13 shows subjective priority probability of perspectives. The results indicate that all the multiple perspectives are important. The subjective priority probability of the perspectives ranges from relative values of 0.222 to 0.306. The total is 1.00 for all four perspectives. By evaluating and ranking the scores for each perspective, the finding is that environmental perspective stands out. When we analyze criteria in each perspective, the perspective weight will be removed, so the sum of weights of criteria under each perspective is normalized to 1. From the technological perspective, Area requirement, Engineering requirement, and Reliability all have highest weight (Figure 14). From the economic perspective, Setup cost and Revenue are more important others (Figure 15). From the social perspective, Safety and Health stand out (Figure 16). From the Environmental perspective, Water Contamination and Hazardous By-products have highest weight and equal important (Figure 17).

TABLE 5 - SURVEY RESULTS OF ALL CRITERIA

\begin{tabular}{|c|c|c|c|c|c|c|c|c|c|c|c|c|c|c|c|c|c|c|c|c|}
\hline \begin{tabular}{|l|} 
Technology Assessment \\
\end{tabular} & \begin{tabular}{|l|} 
Adaptibility \\
\end{tabular} & Efficiency & Area Req & Eng Req & Reliability & Duration & Setup Costs & Labor Costs & Revenue & Maint \& Op Cost & Transportation & Safety & Health & Todor & Emp Creation & Haz byprod & Soil Cont & Water Cont & Air Pollution & Inconsistency \\
\hline \begin{tabular}{|l|} 
Expert 1 \\
\end{tabular} & 0.04 & 0.03 & 0.04 & 0.04 & 0.04 & 0.04 & 0.09 & \begin{tabular}{|l|}
0.03 \\
\end{tabular} & 0.05 & 0.08 & \begin{tabular}{|l|}
0.02 \\
\end{tabular} & 0.05 & 0.07 & 0.03 & 0.03 & \begin{tabular}{|l|}
0.06 \\
\end{tabular} & 0.07 & \begin{tabular}{|l|}
0.1 \\
\end{tabular} & \begin{tabular}{|l|}
0.09 \\
\end{tabular} & 0.01 \\
\hline Expert2 & 0.03 & 0.03 & 0.04 & 0.04 & 0.04 & 0.04 & 0.08 & 0.04 & 0.05 & 0.04 & 0.01 & 0.09 & 0.08 & 0.08 & 0.05 & 0.08 & 0.07 & 0.07 & 0.07 & 0.05 \\
\hline Expert 3 & 0.03 & 0.03 & 0.06 & 0.05 & 0.04 & 0.02 & 0.03 & 0.02 & 0.07 & 0.02 & 0.01 & 0.1 & 0.11 & 0.06 & 0.05 & 0.09 & 0.07 & 0.07 & 0.05 & 0.02 \\
\hline Expert 4 & 0.04 & 0.04 & 0.03 & 0.04 & 0.04 & 0.03 & 0.04 & 0.09 & 0.07 & 0.08 & 0.05 & 0.06 & 0.05 & 0.03 & 0.04 & 0.08 & 0.05 & 0.07 & 0.05 & 0.01 \\
\hline Expert5 & 0.03 & 0.04 & 0.02 & 0.03 & 0.06 & 0.03 & 0.04 & 0.03 & 0.05 & 0.03 & 0.02 & 0.1 & 0.08 & 0.04 & 0.03 & 0.07 & 0.1 & 0.1 & 0.1 & 0.01 \\
\hline Mean & 0.03 & 0.03 & 0.04 & 0.04 & 0.04 & 0.03 & 0.06 & 0.04 & 0.06 & 0.05 & 0.02 & 0.08 & 0.08 & 0.05 & 0.04 & 0.08 & 0.07 & 0.08 & 0.07 & \\
\hline \begin{tabular}{|l|} 
Minimum \\
\end{tabular} & 0.03 & 0.03 & 0.02 & 0.03 & 0.04 & 0.02 & 0.03 & 0.02 & 0.05 & 0.02 & 0.01 & 0.05 & 0.05 & 0.03 & 0.03 & 0.06 & 0.05 & 0.07 & 0.05 & \\
\hline Maximum & 0.04 & 0.04 & 0.06 & 0.05 & 0.06 & 0.04 & 0.09 & 0.09 & 0.07 & 0.08 & 0.05 & 0.1 & 0.11 & 0.08 & 0.05 & 0.09 & 0.1 & 0.1 & 0.1 & \\
\hline Std. Deviation & 0 & 0 & 0.01 & 0.01 & 0.01 & 0.01 & 0.02 & 0.02 & 0.01 & 0.03 & 0.01 & 0.02 & 0.02 & 0.02 & 0.01 & 0.01 & 0.02 & 0.01 & 0.02 & \\
\hline \begin{tabular}{|l|} 
Disagreement \\
\end{tabular} & & & & & & & & & & 0.0 & 01 & & & & & & & & & \\
\hline
\end{tabular}

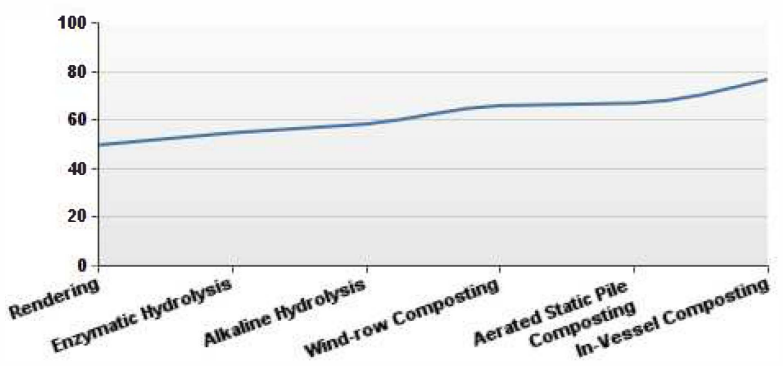

Figure 11 Adaptability Desirability Function

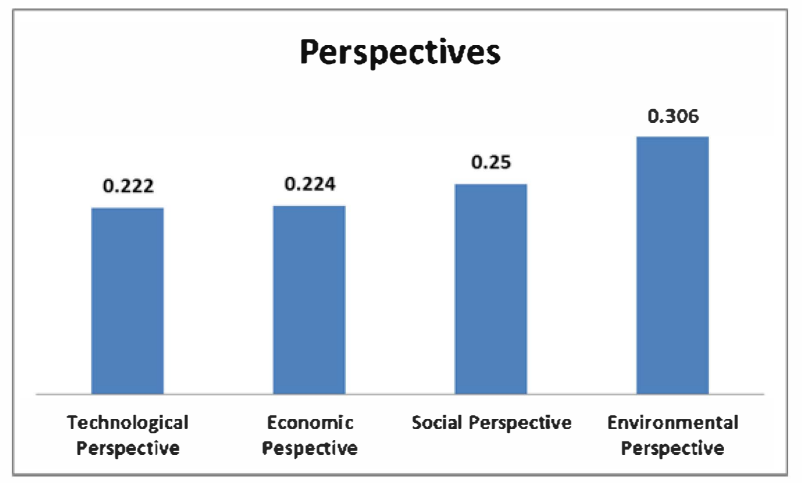

Figure 13 - Perspective Score

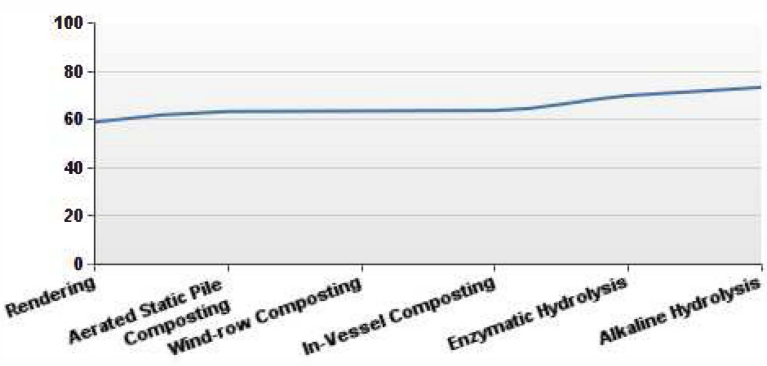

Figure 12 Efficiency Desirability Function

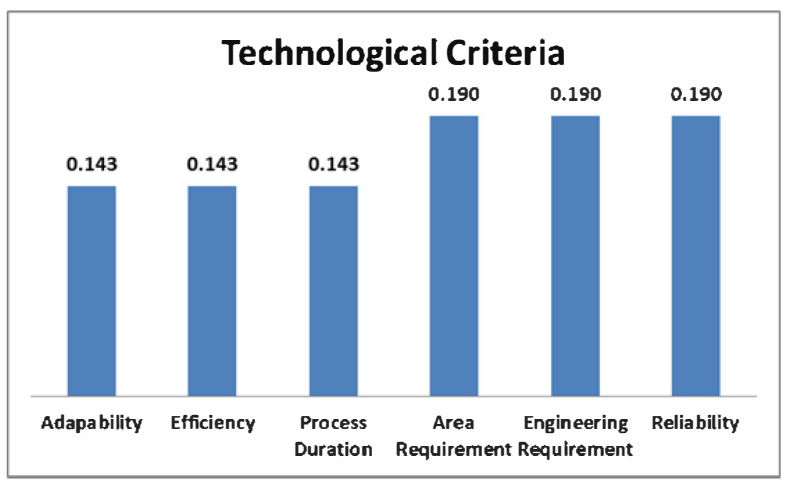

Figure 14 - Technological Criteria Score 


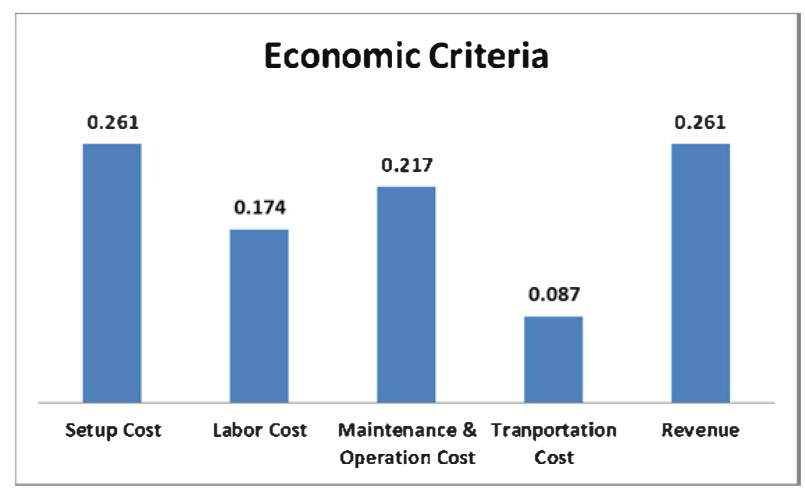

Figure 15 - Economic Criteria Score

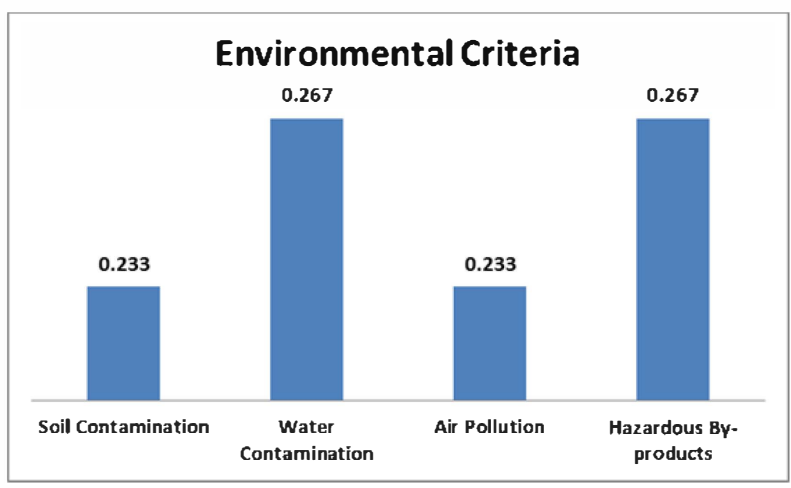

Figure 17 - Environmental Criteria Score

The table 6 demonstrates highest and lowest subjective priority criteria in each perspective. The table 7 below shows desirability values for six candidate waste management technologies and overall score against all perspectives. The finding from table 7 is that Alkaline Hydrolysis has the highest score among six candidate technologies. Alkaline Hydrolysis has highest score in the technological, economic, and social perspectives (Table 8, Table 9, and Table 10). Enzymatic Hydrolysis is a little bit better than Alkaline Hydrolysis (Table 11).

The equation below is used to calculate the overall score each technology.

$$
T_{j}=\sum_{i=1}^{19} W_{i j} D_{i j}
$$

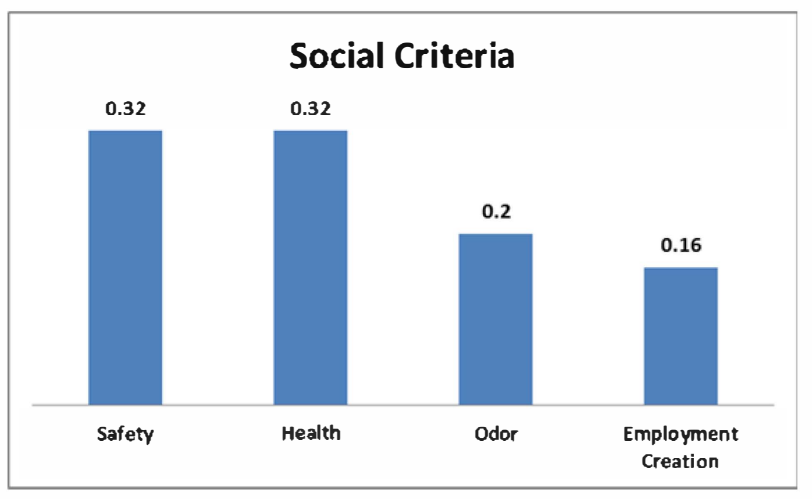

Figure 16 - Social Criteria Score

$\mathrm{j} \in$ (Windrow Composting, Static Pile Composting, In-Vessel Composting, Rendering, Enzymatic hydrolysis, and Alkaline Hydrolysis)

$W_{i j}$ - Weight of criteria

$D_{i j}$ - Desired value of the technology against each criteria

The equation below is used to calculate the score of technologies against each perspective. When we calculate score of technologies against each perspective, the perspective weight will be removed, so the sum of weights of criteria under each perspective is normalized to 1 .

$$
T_{j}=\sum_{i=1}^{n} W_{i j} D_{i j}
$$

n $€(6$ - technical perspective, 5- economic perspective, 4 social and environmental perspective)

$\mathrm{j} \in$ (Windrow Composting, Static Pile Composting, In-Vessel

Composting, Rendering, Enzymatic hydrolysis, and Alkaline Hydrolysis)

$W_{i j}$ - Weight of criteria

$D_{i j}$ - Desired value of the technology against each criteria

Table 7 shows the score differences between technologies are not very significant. A technology may have high score against some criteria but low score against others. Decision makers may have to go through each criteria in each perspective and see which criteria is most important for the project and make final decision if the overall performance scores are close enough. It makes sense that Enzymatic Hydrolysis and Alkaline Hydrolysis have a similar score because they are a similar technology.

TABLE 6 - HIGHEST AND LOWEST PRIORITY CRITERIA IN EACH PERSPECTIVE

\begin{tabular}{|l|l|l|}
\hline \multicolumn{1}{|c|}{ Perspective } & \multicolumn{1}{|c|}{ Highest Priority Criteria } & \multicolumn{1}{c|}{ Lowest Priority Criteria } \\
\hline Technological & Area Requirement, Engineering requirement, and Reliability & Adaptability, Efficiency, and Process Duration \\
\hline Economic & Setup Cost and Revenue & Transportation Cost \\
\hline Social & Safety and Health & Employment Creation \\
\hline Environmental & Water Contamination and Hazardous By-products & Soil Contamination and Air Pollution \\
\hline
\end{tabular}




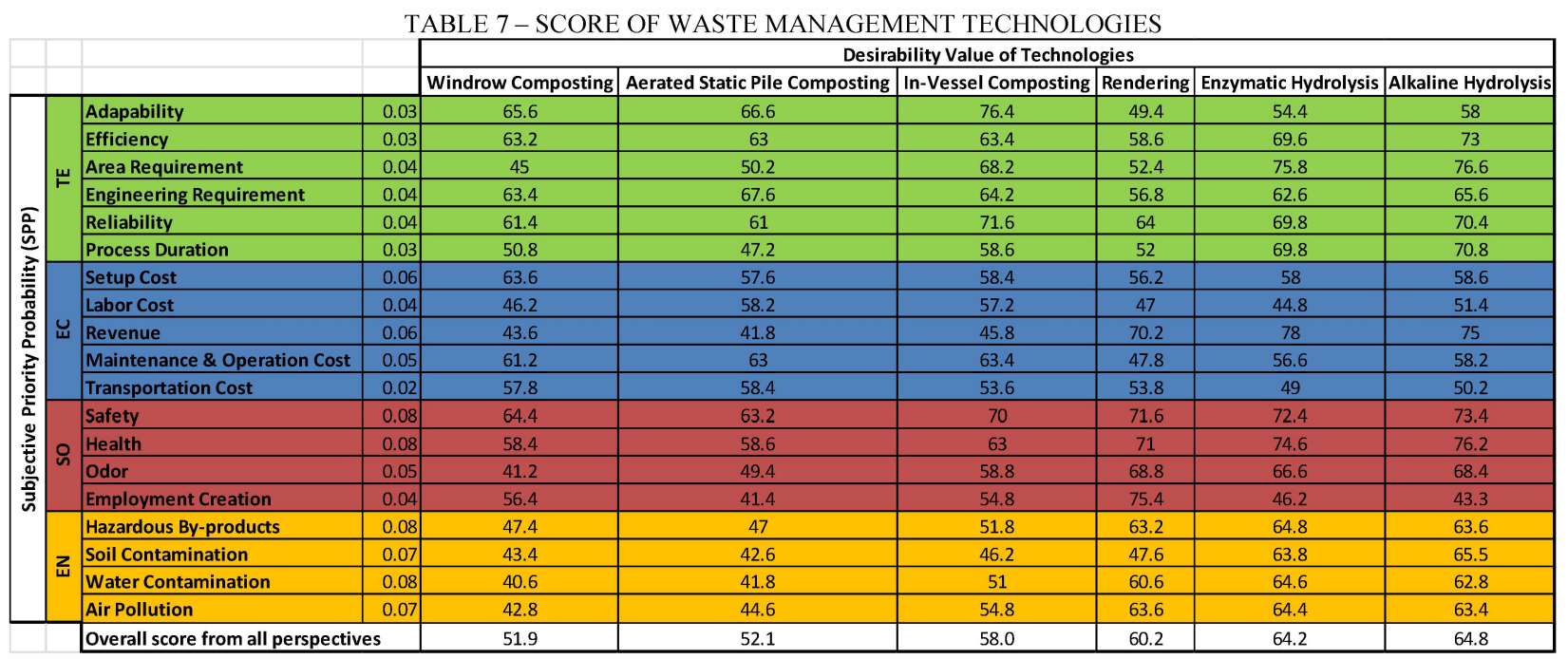

TABLE 8 - SCORE FROM THE TECHNOLOGICAL PERSPECTIVE

\begin{tabular}{|c|c|c|c|c|c|c|c|c|}
\hline & \multirow[b]{2}{*}{ Criteria } & \multirow[b]{2}{*}{ Score } & \multicolumn{6}{|c|}{ Desirability Value of Technologies } \\
\hline & & & Windrow Composting & Aerated Static Pile Composting & In-Vessel Composting & Rendering & Enzymatic Hydrolysis & Alkaline Hydrolysis \\
\hline \multirow{7}{*}{ 㐔 } & Adapability & 0.143 & 65.6 & 66.6 & 76.4 & 49.4 & 54.4 & 58 \\
\hline & Efficiency & 0.143 & 63.2 & 63 & 63.4 & 58.6 & 69.6 & 73 \\
\hline & Area Requirement & 0.143 & 45 & 50.2 & 68.2 & 52.4 & 75.8 & 76.6 \\
\hline & Engineering Requirement & 0.19 & 63.4 & 67.6 & 64.2 & 56.8 & 62.6 & 65.6 \\
\hline & Reliability & 0.19 & 61.4 & 61 & 71.6 & 64 & 69.8 & 70.4 \\
\hline & Process Duration & 0.19 & 50.8 & 47.2 & 58.6 & 52 & 69.8 & 70.8 \\
\hline & \multicolumn{2}{|c|}{ Score from technological perspective } & 58.3 & 59.2 & 66.7 & 55.8 & 67.1 & 69 \\
\hline
\end{tabular}

TABLE 9 - SCORE FROM THE ECONOMIC PERSPECTIVE

\begin{tabular}{|c|c|c|c|c|c|c|c|c|}
\hline & \multirow[b]{2}{*}{ Criteria } & \multirow[b]{2}{*}{ Score } & \multicolumn{6}{|c|}{ Desirability Value of Technologies } \\
\hline & & & Windrow Composting & Aerated Static Pile Composting & In-Vessel Composting & Rendering & Enzymatic Hydrolysis & Alkaline Hydrolysis \\
\hline \multirow{5}{*}{ in } & Setup Cost & 0.261 & 63.6 & 57.6 & 58.4 & 56.2 & 58 & 58.6 \\
\hline & Labor Cost & 0.174 & 46.2 & 58.2 & 57.2 & 47 & 44.8 & 51.4 \\
\hline & \begin{tabular}{|l|} 
Revenue \\
\end{tabular} & 0.217 & 43.6 & 41.8 & 45.8 & 70.2 & 78 & 75 \\
\hline & Maintenance \& Operation Cost & 0.087 & 61.2 & 63 & 63.4 & 47.8 & 56.6 & 58.2 \\
\hline & Transportation Cost & 0.261 & 57.8 & 58.4 & 53.6 & 53.8 & 49 & 50.2 \\
\hline \multicolumn{3}{|c|}{ Score from economic perspective } & 54.5 & 54.9 & 54.6 & 56.3 & 57.6 & 58.7 \\
\hline
\end{tabular}

TABLE 10 - SCORE FROM THE SOCIAL PERSPECTIVE

\begin{tabular}{|c|c|c|c|c|c|c|c|c|}
\hline & \multirow[b]{2}{*}{ Criteria } & \multirow[b]{2}{*}{ Score } & \multicolumn{6}{|c|}{ Desirability Value of Technologies } \\
\hline & & & Windrow Composting & Aerated Static Pile Composting & In-Vessel Composting & Rendering & Enzymatic Hydrolysis & Alkaline Hydrolysis \\
\hline \multirow{4}{*}{$\hat{\hat{n}}$} & Safety & 0.32 & 64.4 & 63.2 & 70 & 71.6 & 72.4 & 73.4 \\
\hline & Health & 0.32 & 58.4 & 58.6 & 63 & 71 & 74.6 & 76.2 \\
\hline & Odor & 0.2 & 41.2 & 49.4 & 58.8 & 68.8 & 66.6 & 68.4 \\
\hline & Employment Creation & 0.16 & 56.4 & 41.4 & 54.8 & 75.4 & 46.2 & 43.3 \\
\hline \multicolumn{3}{|c|}{ Score from social perspective } & 56.6 & 55.5 & 63.1 & 67.8 & 67.8 & 68.5 \\
\hline
\end{tabular}

TABLE 11 - SCORE FROM THE ENVIRONMENTAL PERSPECTIVE

\begin{tabular}{|c|c|c|c|c|c|c|c|c|}
\hline & \multirow{2}{*}{ Criteria } & \multirow{2}{*}{ Score } & \multicolumn{6}{|c|}{ Desirability Value of Technologies } \\
\hline & & & Windrow Composting & Aerated Static Pile Composting & In-Vessel Composting & Rendering & Enzymatic Hydrolysis & Alkaline Hydrolysis \\
\hline \multirow{4}{*}{ in } & Hazardous By-products & 0.233 & \begin{tabular}{|c|}
47.4 \\
\end{tabular} & 47 & 51.8 & 63.2 & \begin{tabular}{|c|}
64.8 \\
\end{tabular} & 63.6 \\
\hline & \begin{tabular}{|l|} 
Soil Contamination \\
\end{tabular} & 0.267 & 43.4 & 42.6 & 46.2 & 47.6 & 63.8 & 65.5 \\
\hline & Water Contamination & 0.233 & 40.6 & 41.8 & 51 & 60.6 & 64.6 & 62.8 \\
\hline & \begin{tabular}{|l|} 
Air Pollution \\
\end{tabular} & 0.267 & 42.8 & 44.6 & 54.8 & 63.6 & 64.4 & 63.4 \\
\hline \multicolumn{3}{|c|}{ Score from environmental perspective } & 43.5 & 44 & 50.9 & 58.5 & 64.4 & 63.9 \\
\hline
\end{tabular}

\section{CONCLUSION}

Tillamook County is looking for alternative technologies to manage waste products in environment-friendly manner. Technologies should not only assist growth and development in the dairy industry but also minimize environmental, economic, and public health impacts. A two-level filter is developed to assess waste management technologies using technological, economic, social, and environmental perspectives. Pair-wise and constant sum are used to prioritize the criteria against all perspectives. Desirability functions are created to map criterion performance measures 
to desirability values. The filter model is used to evaluate six candidate waste management technologies: Windrow Composting, Aerated Static Pile Composting, In-vessel Composting, Rendering, Enzymatic Hydrolysis, and Alkaline Hydrolysis. Alkaline Hydrolysis is the top ranked technology followed by Enzymatic Hydrolysis. Windrow Composting has the lowest score in all candidate waste management technology. In the composting technologies, In-Vessel Composting stands out. Rendering scores well - regulations in State are tightening and low volume of feedstock resulting in closure of all facilities - USA 1990s - 900 plants at present less than 200. Enzymatic Hydrolysis and Alkaline Hydrolysis are very close because they are in the same category of technologies. Environmental concern is high in all technologies analyzed, alkaline hydrolysis has least impact on environment but it isn't so cost effective.

\section{LIMITATION AND FUTURE RESEARCH}

Because of the time limitation, we used the proposed model to evaluate six selected technologies. When other technologies are added into the evaluation list, the recommended technology may be different. HDM is a good methodology to subjectively rank perspectives and criteria for waste management technology assessment. These perspective and criteria may change with time and different decision makers [39].

The score difference between technologies are not very significant; the results may mean these technologies have similar overall performance. Or, it may also mean high variability in the individual scores used to assess the technology. We need to investigate this in further research, and define the minimal level of significant difference, as we calculate go or no-go decision.

Future research needs to evaluate all technologies and updates to the model may provide better recommendations. Sensitivity analysis may be used to assess waste management decisions as priorities, situations, and technologies change.

\section{REFERENCES}

[1] Tetra Tech, Inc., "Tillamook County Bioenergy Feasibility Study Report," August 2011. [Online]. Available: http://www.co.tillamook.or.us/gov/sol idwaste/(1)Documents/Tillamo okBioenergyFSFinalReport(03-12).pdf. [Accessed 27 July 2014].

[2] T. A. Tran and T. Daim, "A taxonomic review of methods and tools applied in technology assessment," Technological Forecasting \& Social Change, vol. 75, pp. 1396-1405, 2008.

[3] J. F. Coates, "The role of formal models in technology assessment," Technological Forecasting and Social Change, vol. 9, no. 1-2, pp. 139-190, 1976.

[4] L. Kessler, "Technology Assessment Framework for Waste Disposal in Tillamoon County," Portland State University, Portland, Oregon, 2014.

[5] R. Janikowski, R. Kucharski and A. Sas-Nowosielska, "Multi-Criteria and Multi-Perspective Analysis of Contaminated Land Management Methods," Environmental Monitoring and Assessment, vol. 60, no. 1, pp. $89-102,2000$.
[6] Assistant Secretary of Defense for Research and Engineering, "Technology Readiness Assessment (TRA) Guidance 2011," 11 May 2011. [Online]. Available: https://acc.dau.mil/CommunityBrowser.aspx?id=461216. [Accessed 27 July 2014].

[7] D. Engel, A. Dalton, K. Anderson, C. Sivaramakrishnan and C. Lansing, October 2012. [Online]. Available: http://www.pnnl.gov/main/publications/external/technical_reports/PN NL-21737.pdf. [Accessed 26 July 2014].

[8] J. C. Mankins, "Technology Readiness Levels," 6 April 1995 [Online]. Available: http://www.hq.nasa.gov/office/codeq/trl/trl.pdf. [Accessed 26 July 2014].

[9] T. Moon, J. Smith and S. Cook, "Technology Readiness and Technical Risk Assessment for the Australian Defence Organisation," [Online]. Available: http://www.dsto.defence.gov.au/publications/4256/Technology\%20Re adiness\%20and\%20Technical\%20Risk.pdf. [Accessed 26 July 2014].

[10] R. Sanchez, "Technology Readiness Assessment Guide," 15 September 2011. [Online]. Available: https://www.directives.doe.gov/directives-documents/0413.3-EGuide04a. [Accessed 27 July 2014].

[11] J. Smith, "An Alternative to Technology Readiness Levels for NonDevelopmental Item (NDI) Software," in Proceedings of the 38th Annual Hawaii International Conference System Sciences, Waikoloa, Hawaii 06738, 2005.

[12] R. Valerdi and R. J. Kohl, "An Approach to Technology Risk Management," in Engineering Systems Division Symposium, Cambridge, MA, 2004.

[13] L. Diaz, M. d. Bertoldi, W. Bidlingmaier and a. E. Stentiford, "Compost Science and Technology," in Chapter 2 History of composting, Boston, Elsevier Science, 2007, pp. 7-24.

[14] "Evaluation of New and Emerging Solid Waste Management Technologies," 16 September 2004. [Online]. Available: http://www.nyc.gov/html/dsny/downloads/pdf/swmp_implement/othe rinit/wmtech/phase1.pdf. [Accessed 27 July 2014].

[15] Government of Alberta, "Livestock Mortality Management (Disposal)," [Online]. Available: http://wwwl.agric.gov.ab.ca/\$Department/deptdocs.nsf/all/agdex6081 /\$FILE/400_29-1.pdf. [Accessed 27 July 2014].

[16] N. G. Willis, "Animal Carcass Disposal," 2003. [Online]. Available: http://www.oie.int/doc/ged/D2964.PDF. [Accessed 27 July 2014].

[17] the National Agricultural Biosecurity Center Consortium Carcass Disposal Working Group, "Carcass Disposal:A Comprehensive Review," March 2004. [Online]. Available: http://amarillo.tamu.edu/files/2011/01/draftreport.pdf. [Accessed 26 July 2014].

[18] Council for Agricultural Science and Technology, January 2009. [Online]. Available: http://extension.umaine.edu/ByproductsSymposium09/compendium/C AST_Ruminant_Carcass_Disposal_Issue_Paper_41,_Web_Optimized _FINAL.pdf. [Accessed 26 July $20 \overline{1} 4$ ].

[19] Parsons Corporation, "Emerging Technologies for Biosolids Management," September 2006. [Online]. Available: http://water.epa.gov/scitech/wastetech/upload/2007_04_24_mtb_epabiosolids.pdf. [Accessed 26 July 2014].

[20] J. Shearer, M. Irsik and E. Jennings, "Methods of Large Animal Carcass Disposal in Florida," June 2008. [Online]. Available: http://edis.ifas.ufl.edu/pdffiles/VM/VM13300.pdf. [Accessed 26 July 2014].

[21] M. J. Taherzadeh and K. Karim, "Acid-Based Hydrolysis Processes for Ethanol from Lignocellulosic Materials: A Review," [Online]. Available:

http://www.ncsu.edu/bioresources/BioRes_02/BioRes_02_3_472_499 _Taherzadeh_K_BioEthanol_Review.pdf. [Accessed 13 July 2014]. 
[22] National Renders Association, Inc., "North American Rendering," [Online]. Available: http://assets.nationalrenderers.org/north_american_rendering_v2.pdf. [Accessed 1 August 2014].

[23] Cascade Economics LLC, "Animal Byproduct Technology Assessment and Market Analysis: Options for Oregon," Cascade Economics, Washougal, 2007.

[24] D. L. Meeker, "Essential Rendering:All about the Animal Byproduct Industry," National Renderers Association, 2006. [Online]. Available: http://assets.nationalrenderers.org/essential_rendering_book.pdf. [Accessed 10 August 2014].

[25] Cool 2012, "Composting methods \& technologies," [Online] Available: http://www.cool2012.com/tools/technologies/. [Accessed 09 August 2014].

[26] W. Bidlingmaier, "The Science of Composting," in Odour emissions from composting plants, Springer Netherlands, 1996, pp. 71-80.

[27] H. Martin, "Agricultural Composting Basics," Ontario Ministry of Agriculture, Food and Rural Affairs, March 2005. [Online]. Available: http://www.omafra.gov.on.ca/english/engineer/facts/05023.htm. [Accessed 09 August 2014].

[28] M. J. Taherzadeh and K. Karimi, "Enzyme-Based Hydrolysis Process for Ethanol From Lignocellusic Material : a review," vol. 4, no. 2, pp. 707-739, 2007.

[29] D. Hayes, M. H. Hayes, J. Leahy, D. Haverty, K. Dussan, G. Molteni, A. o. Driscoll and M. Ashworth, "Carbolea," [Online]. Available: http://www.carbolea.ul.ie/area.php?=biorefining. [Accessed 15 July 2014].

[30] P. Alvira, E. Tomás-Pejó, M. Ballesteros and M. J. Negro, "Pretreatment technologies for an efficient bioethanol production process based on enzymatic hydrolysis: A review," ELSEVIER, pp. 4852-4861, 2009.

[31] A. Verardi, I. D. Bari, E. Ricca and V. Calabro, "Hydrolysis of Lignocellulosic Biomass: Current Status of Processes and Technologies and Future Perspectives," in Bioethanol, Intech, 2012, pp. 97-122.
[32] P. Kumar, D. M. Barret, M. J. Delwiche and P. Stroeve, "Methods for Pretreatment of Lignocellulosic Biomass for Efficient Hydrolysis and," American Chemical Society, vol. 48, pp. 3713-3729, 2009.

[33] D. Hayes, "Second-generation biofuels: why they are taking so long," in Wiley: Interdisciplinary Reviews: Energy and Enviroment, 2013, pp. 304-334.

[34] N. Eriksen, "Novozymes," [Online]. Available: http://www.novozymes.com/en/investor/eventspresentations/Documents/Inbicon\%20investor\%20day.pdf. [Accessed 8 July 2014].

[35] A. Aden, M. Ruth, K. Ibsen, J. Jechura, K. Neeves, J. Sheenhan, B Wallce, L. Montague, A. Slayton and J. Lukas, "Lignocellulosic Biomass to Ethanol Process Design and Economics Utilizing CoCurrentDilute Acid Prehydrolysis andEnzymatic Hydrolysis for Corn Stover," National Renewable Energy laboratory, Golden, 202.

[36] S. Jones, "Alkaline Hydrolysis, Part 1: The History, The Process, \& Today's Market," 24 June 2010. [Online]. Available: http://www.alnmag.com/articles/2010/06/alkaline-hydrolysis-part-1history-process-today\%E2\%80\%99s-market. [Accessed 12 August 2014].

[37] Christopher Kiley, PE and Shanon Jones, "Alkaline Hydrolysis, Part 2: The selection process," 9 July 2010. [Online]. Available: http://www.alnmag.com/articles/2010/09/alkaline-hydrolysis-part-2selection-process. [Accessed 12 August 2014].

[38] H. L. Thacker, "Carcass Disposal: A comprehensive Review," National Agricultural Biosecurity Center, Kansas State University, 2004.

[39] N. J. Sheikh, "Assessment of Solar Photovoltaic Technologies Using Multiple Perspectives and Hierarchical Decision Modeling," Dissertations and Theses, Paper978, 2013. 